\title{
Age-Related Loss of Cohesion: Causes and Effects
}

\author{
Jin-Mei Cheng ${ }^{1,2}$ and Yi-Xun Liu ${ }^{1, *}$ \\ 1 State Key Laboratory of Stem Cell and Reproductive Biology, Institute of Zoology, \\ Chinese Academy of Sciences, Beijing 100101, China; chengjinmeixdg@163.com \\ 2 Institute of Reproductive Medicine, School of Medicine, Nantong University, Nantong 226001, China \\ * Correspondence: liuyx@ioz.ac.cn; Tel./Fax: +86-010-6480-7038
}

Received: 18 June 2017; Accepted: 19 July 2017; Published: 22 July 2017

\begin{abstract}
Aneuploidy is a leading genetic cause of birth defects and lower implantation rates in humans. Most errors in chromosome number originate from oocytes. Aneuploidy in oocytes increases with advanced maternal age. Recent studies support the hypothesis that cohesion deterioration with advanced maternal age represents a leading cause of age-related aneuploidy. Cohesin generates cohesion, and is established only during the premeiotic $S$ phase of fetal development without any replenishment throughout a female's period of fertility. Cohesion holds sister chromatids together until meiosis resumes at puberty, and then chromosome segregation requires the release of sister chromatid cohesion from chromosome arms and centromeres at anaphase I and anaphase II, respectively. The time of cohesion cleavage plays an important role in correct chromosome segregation. This review focuses specifically on the causes and effects of age-related cohesion deterioration in female meiosis.
\end{abstract}

Keywords: age; cohesion; aneuploidy; oocytes

\section{Introduction}

In both males and females, meiosis consists of two rounds of chromosome segregation following a single round of DNA replication, which produces the haploid sperm or egg. Deteriorating effect of the mutant type on sperm characteristics does not impact on embryo development after fertilization in vitro [1]. Male meiosis occurs post-puberty with waves of spermatogenesis that produce mature sperm. Conversely, in females, meiosis initiates during fetal development and has two cell cycle arrests at the germinal vesicle (GV) and metaphase II (MII). This long time interval means that maternal age can affect chromosome separation to produce aneuploidy. Numerous studies have reported that the aneuploid rate in oocytes increases along with maternal age [2-6]. For example, Cheng et al. observed that the incidence of aneuploidy in older mice (31.6\%, 12 months) was significantly increased compared with young mice (4.9\%, 1 month) [2]. Merriman et al. found that this rate could reach up to $60 \%$ in 15 month old mice [3]. In humans, the incidence of aneuploidy increases from $20 \%$ in patients who are 35 years of age to over $40 \%$ in patients who are 40 years of age [5,6]. Regarding the origin of aneuploidy in oocytes, genetically altered animals and natural aging models both support the hypothesis that the deterioration of cohesion with increasing maternal age represents a leading cause of age-related aneuploidy [7-10], and this hypothesis has been reviewed in detail by Jessberger [8] and Chiang [10]. Although premature bivalent separation into univalent [11] or altered microtubule-kinetochore interactions [12] during meiosis I has been suggested as the primary defect responsible for age-related aneuploidy, both events have a tight correlation with age-related cohesion deterioration [13-15]. In this report, we review recent data on factors that determine the cause of age-related cohesion deterioration and discuss the relationship between cohesion deterioration and some factors associated with chromosome segregation errors. 


\section{Mammalian Cohesion}

Sister chromatids are kept together by the cohesin complex, which generates sister chromatid cohesion [16]. The cohesin complex is a ring-like protein structure wrapped around chromosome centromeres and arms $[17,18]$ (Figure 1B,C). Chromosome segregation requires the release of sister chromatid cohesion from chromosome arms at anaphase I, which permits chiasmata resolution and the segregation of homologous chromosomes. However, centromeric cohesin in meiosis I is protected by Shugoshin until the metaphase II to anaphase II transition, when it is resolved to ensure proper sister chromatid segregation. The timing of cohesin cleavage and where it occurs both play a vital role in correct chromosome segregation.

In mice and humans, the cohesin complex comprises two structural maintenance of chromosomes (Smc) proteins, Smc1 $\beta$ and Smc3, which heterodimerize to form a large V-shaped structure [19-21]. The open side of the cohesin complex is closed by a member of the kleisin protein family, Rec8, which ultimately forms a tripartite ring [22-25]. A fourth protein, Stag3, associates with the kleisin and forms the complex $[22,26,27]$ (Figure 1A).
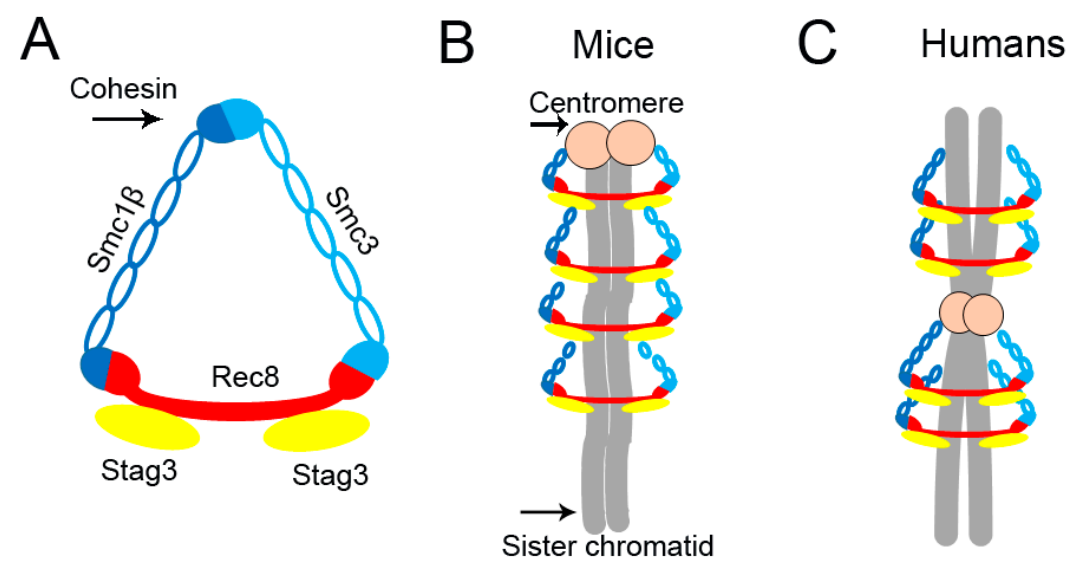

Figure 1. Schematic of cohesin structure in mice and humans. (A) The cohesin complex comprises four subunits, Smc1 $\beta$, Smc3, Stag3 and Rec8, and surrounds sister chromatids in a ring-like protein structure in mice (B) and humans (C).

Kleisin Rec8 has an essential role in mammalian meiosis in that Rec8-null mice of both sexes have germ cell failure and are sterile [28]. Rec8 is a meiosis-specific cohesin protein [24,29] and it appears shortly before the premeiotic $S$ phase in the nucleus [24,30]. Rec8 is cleaved by separase, which is necessary for chromosome segregation [31]. In oocytes from old mice, chromosome-associated Rec8 is severely reduced, which is a leading cause of chromosome segregation errors [32,33]. Chromosome segregation must be accurate because the Rec 8 variant is not substantially reduced during female fertility [31]. In other words, a threshold level of Rec8 is necessary to prevent errors, which may be $\sim 10 \%$ or less than the starting amount, and only after chromosome-associated Rec 8 reaches this threshold does the number of chromosome segregation errors increase [32]. On the other hand, Tachibana-Konwalski et al. [34] demonstrated that Rec8-containing cohesin maintained bivalents without turnover during the growth phase of mouse oocytes. In 2016, Burkhardt et al. found that Rec8-Myc was capable of establishing functional cohesion when it was activated before meiosis, but that it cannot be activated after meiotic DNA replication in fetal oocytes [35]. In mouse female meiosis, they posited the hypothesis that the inability of oocytes to build cohesion during the dictyate arrest that lasts for months or decades contributes to the maternal age-related chromosome missegregation and the production of aneuploidy fetuses [35]. In addition, cohesin subunit Smc1 $\beta$ has also been reported to be expressed only during prophase I prior to the primordial follicle stage to ensure sister chromatid cohesion until mice reach an advanced age $[9,36]$. Therefore, the inability of oocytes to reload cohesion 
on a chromosome during prolonged prophase arrest is one of the important causes of age-related chromosome segregation errors. Although new cohesive linkages that are established after meiotic $S$ phase by Nipped B and the acetyltransferase Eco in Drosophila oocytes have been demonstrated [37], the rejuvenation program can no longer supply new cohesive linkages at the same rate at which they are lost during maternal aging [34,37].

\section{The Cause of Age-Related Loss of Cohesion}

\subsection{Increased Sensibility of Separase}

Anaphase is triggered when ring-shaped cohesion is cleaved by separase, which is a large cysteine endopeptidase that cleaves the kleisin subunit of cohesin (Scc1/Rad21 in mitosis, Rec8 in meiosis) [38-40]. Before anaphase, the activity of separase is inhibited by two independent mechanisms: Binding to securin and inhibitory phosphorylation by cyclin-dependent kinase Cdk1 [41,42]. Cdk1 stably binds to phosphorylated separase via its regulatory cyclin B1 subunit [43]. The AA-separase mutant (AA-separase) is constructed by mutating both CDK1 phosphorylation sites, including S1121A and T1342A [42]. Depletion of securin is induced through the injection of morpholino (MO) antisense oligonucleotides [44]. When the cytoplasm of germinal vesicle-intact oocytes are microinjected with securin $\mathrm{MO}$, AA-separase cRNA, or AA-separase cRNA and securin MO together $(\mathrm{AA}+\mathrm{MO})$, all chromosomes in meiosis I are intact in uninjected, AA-separase, and securin MO oocytes, whereas the majority of $\mathrm{AA}+\mathrm{MO}$ oocytes show premature separation of both bivalents and sister chromatids [45]. Therefore, both mechanisms must be disrupted to prematurely activate separase. In addition, lower concentrations of both AA-separase cRNA and securin MO can significantly cause more old oocytes with prematurely separated bivalents and sister chromatids compared with young oocytes [45]. Specifically, cohesin can be removed by the low activity of separase in aged mouse oocytes. Given that the proteolytic activity of separase is essential for Rec8's removal from chromosome arms [40], it may be possible that leaky separase activation starts after birth and lasts until old age or low levels of separase activity could cause age-related loss of cohesion (Figure 2B).

\subsection{The $S A C$ and $A P C / C^{C d c 20}$}

The loss of cohesion around chromosome arm at the onset of anaphase in mouse oocytes depends on proteolysis of the separase inhibitor securin and the Cdk1 regulatory subunit cyclin B1 [41], which is caused by a ubiquitin protein ligase called the anaphase-promoting complex or cyclosome (APC/C) in association with $\mathrm{Cdc} 20\left(\mathrm{APC} / \mathrm{C}^{\mathrm{Cdc} 20}\right)[46,47]$. Without cyclin B1 and securin degradation, cell cycle progression is halted because $\mathrm{CDK} 1$ activity remains high and chromosome cohesion is maintained. In other words, $\mathrm{APC} / \mathrm{C}^{\mathrm{Cdc} 20}$ indirectly triggers the loss of sister-chromatid cohesion (Figure $2 \mathrm{~A}$ ). However, APC/C must not be activated until chromosome bi-orientation has been completed. The regulatory mechanism responsible for delaying anaphase in this manner is known as the spindle assembly checkpoint (SAC) $[48,49]$. The checkpoint protein Mad2 catalyzes the sequestration of the $\mathrm{APC} / \mathrm{C}^{\mathrm{Cdc} 20}$ activator protein to block its ability to ubiquitinylate either securin or cyclin $\mathrm{B}$ by the Cdc20/Mad2 complex binding to the APC/C when unattached, mono-oriented, or syntelically attached kinetochores exist [50,51]. Depletion of Mad2 through the injection of morpholino antisense oligonucleotides results in aneuploidy and advances the onset of cyclin B and securin destruction [52]. Mad2 overexpression inhibits homolog disjunction [52,53]. Bub1 is a key SAC component, and its loss in oocytes causes precocious loss of cohesion between sister centromeres and massive chromosome missegregation at meiosis I [49], which has also been reported in other cells [54]. Centromeres in Bub1-deficient cells also separate prematurely. However, this separation is a consequence of SAC dysfunction rather than a direct role for Bub1 in protecting centromeric cohesion [54]. Therefore, it is possible that SAC has an important role in the maintenance of cohesion by controlling APC $/ \mathrm{C}^{\mathrm{Cdc} 20}$ activity to operate effective separase activation in oocytes (Figure 2A). In addition, in yeast, Bub1 is necessary for the recruitment to centromeres of Sgo1 that protects cohesin from separase during 
meiosis I [55,56]. Bub1 might act in a similar fashion in oocytes and help to recruit Sgo1 or Sgo2 to centromeres.

In human and mouse oocytes, aging causes a reduction in Mad2 and Bub1 at the transcriptional level [57-59]. Mad2 on kinetochores had a significant $\sim 30 \%$ reduction in oocytes of aged mice at $3 \mathrm{~h}$ after resumption of meiosis I. This reduction was apparent even at $5-7 \mathrm{~h}$ after germinal vesicle breakdown after a $10 \mu \mathrm{M}$ nocodazole treatment [60]. Furthermore, the kinetochore localization of both Bub1 and Bubr1 proteins decreases with age in human oocytes [61]. A recent study indicates that Smc1 $\beta$ is essential for activation of SAC activity during mouse oocyte meiosis [62]. Therefore, there might be some association between decreased kinetochore localization of the SAC proteins and cohesion loss with maternal age, including the possibility that decreased SAC ability in aged oocytes promotes the $\mathrm{APC} / \mathrm{C}^{\mathrm{Cdc} 20}$ to degrade cyclin $\mathrm{B} 1$ and securin, which causes the loss of sister chromatid cohesion [63] (Figure 2A).

\subsection{Premature Shugoshin 2 Degradation}

Two shugoshin isoforms have been identified to protect centromeric cohesin in mammals, specifically Sgo1 and Sgo2 [56,64,65]. Both isoforms are expressed in mouse germ cells, and Sgo1-depleted oocytes similarly exhibit largely intact cohesion of the sister chromatids. By striking contrast, however, separated single chromatids were prevalent in Sgo2-depleted mouse oocytes $[64,66]$. Sgo2 distribution in human oocytes could not be described due to the lack of a working antibody, but mechanisms to protect centromeric cohesion in meiosis are essentially conserved across eukaryotes, including mammals. Therefore, Sgo2 alone plays a predominant role in protecting centromeric cohesion in meiosis I in oocytes, whereas Sgo1 is not required for this function [64,66].

In meiosis I, Sgo2 cooperates with protein phosphatase 2A (PP2A) to protect Rec8 at centromeres from cleavage by separase $[64,67,68]$. Any premature Sgo2 loss in meiosis I would make centromeric cohesin vulnerable to separase-mediated cleavage, which generates single chromatids and has been observed in aged mice [7,69]. The Sgo2 signal on chromosomes in oocytes from 14-month-old mice was obviously reduced by immunostaining [7]. Furthermore, the phenomenon that the largest sister interkinetochore distance tended to have reduced Sgo2 in aged MII oocytes also shows a strong association between an age-related loss in sister chromatid cohesion and reduced Sgo2 [69]. Interestingly, Smc1 $\beta^{-/}$oocytes have reduced levels of chromosome-associated Sgo2 [7], which indicates that the recruitment or retention of Sgo2 is influenced either directly or indirectly by the level of cohesin in mouse oocytes. This phenomenon was also found in maize meiosis [70]. Therefore, reduced levels of chromosome-associated Sgo2 during oocyte aging can give rise to a loss of cohesin, which in turn may amplify loss of Sgo2 (Figure 2B).

Waplin (Wapl) is a cohesin-binding protein that promotes sister-chromatid resolution in mitotic prophase [71,72]. Sororin, which is a substrate of the anaphase-promoting complex, is required for sister chromatid cohesion in vertebrates [73-75]. In human somatic cells, Sgo1 physically shields cohesin from Wapl in addition to recruiting PP2A to dephosphorylate cohesin and sororin [76]. Direct antagonism between Sgo1 and Wapl augments centromeric cohesion protection [76]. This mechanism, or a similar one whether also existing in meiosis remains unknown.

\subsection{Oxidative Damage}

Oxidative damage increases with age in different organisms and cell types [77-79]. In aging cells, the increase in oxidative damage is caused, in large part, by reactive oxygen species (ROS) [80]. The accumulation of oxidative damage over a lifetime negatively impacts oocyte quality, including meiotic division and chromosomal segregation $[78,81,82]$. Antioxidant therapy positively counteracts the bad effects of maternal aging on chromosome segregation in mouse oocytes [83]. How does the oxidative damage influence chromosomal segregation in aged oocytes? Perkins et al. [84] tested the hypothesis that increased oxidative damage in older oocytes may be one of the factors that leads to premature loss of cohesion through knockdown of scavenger superoxide dismutase in the Drosophila 
oocyte. Their results indicate that oxidative damage moderately increases the percentage of oocytes with arm cohesion defects and supports the model that accelerates loss of cohesion in aging human oocytes that is caused, at least in part, by oxidative damage (Figure 2B).

\subsection{Other Factors}

Our lab shows that aged oocytes have a high intracellular $\mathrm{pH}$ value $(\mathrm{pHi})$ and loss of cohesion occurs when young oocytes have a high pHi. Thus, we inferred that dysregulation of $\mathrm{pHi}$ in aged oocytes might damage protein-protein binding affinity or protein localization of cohesion subunits, which leads to deterioration of chromosome cohesion [2] (Figure 2B), but the specific mechanism remains unknown. Other factors might also contribute to cohesion deterioration, such as spontaneous hydrolysis of peptide bonds, cohesion deacetylases and releasins. Cleavage or spontaneous hydrolysis of a single peptide bond at any site within the large cohesin ring could open the tripartite ring and eliminate the topological linkage of two sister chromatids [8]. Loss of histone deacetylase 8 (HDAC8) activity results in increased SMC3 acetylation and inefficient dissolution of the 'used' cohesin complex released from chromatin in both prophase and anaphase of mitosis, which suggests that histone deacetylase may have a role in diminishing centrosome cohesion from chromosomes $[85,86]$. In mitosis, cohesion loading onto chromosomes is mediated by the entry of DNA into cohesion rings, whereas dissociation is mediated by facilitating the exit of DNA via a transiently open Smc3-kleisin interface, which is a process regulated by Smc3 acetylation [87]. However, whether these mechanisms have similar functions in oocyte meiosis or contribute to the loss of cohesion during maternal aging has yet to be demonstrated.
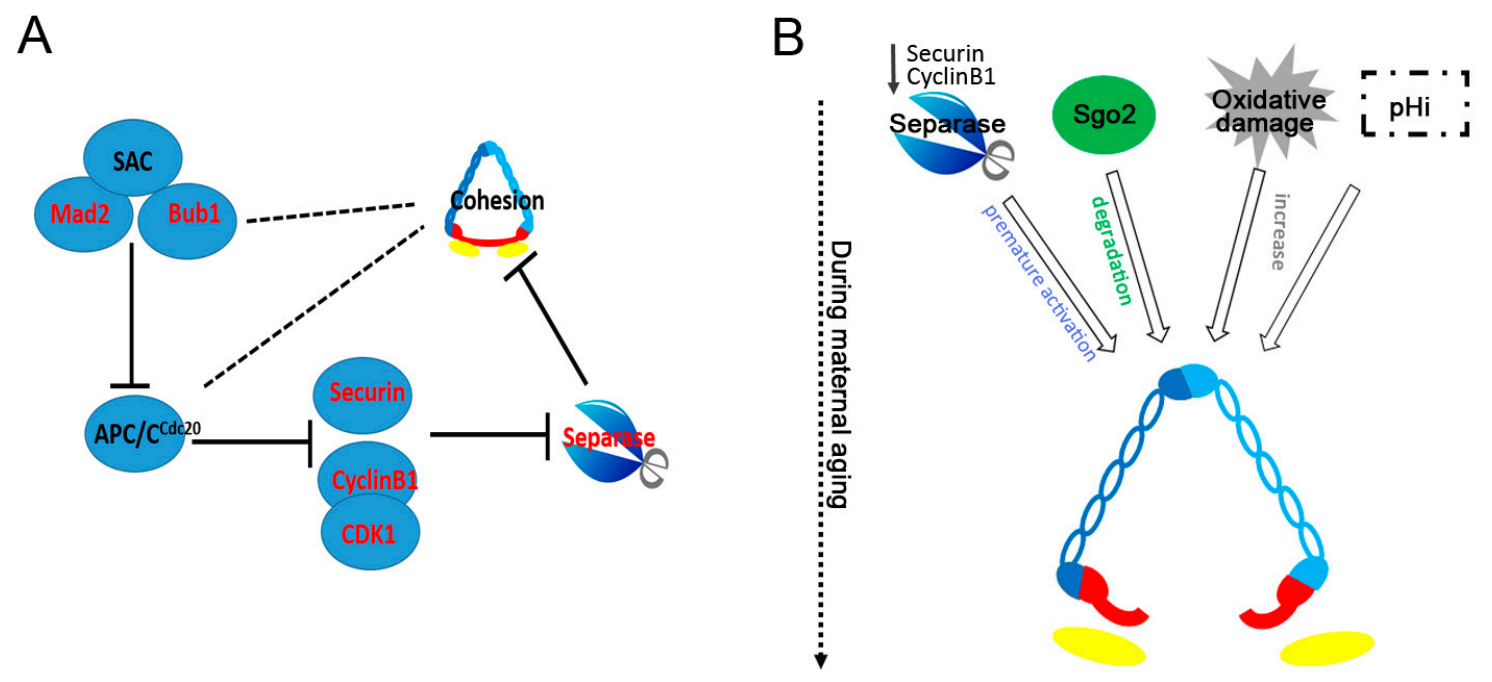

Figure 2. The cohesin-cleaving factors during maternal aging. (A) The correlation between spindle assembly checkpoint (SAC) and anaphase-promoting complex or cyclosome in association with Cdc20 $\left(\mathrm{APC} / \mathrm{C}^{\mathrm{cdc} 20}\right)$ and cohesion. The active SAC causes APC $/ \mathrm{C}^{\mathrm{Cdc} 20}$ inactivation, which cannot degrade securin and cyclin B1 to cause the cleavage of cohesion structure and anaphase onset. Therefore, the SAC and APC $/ \mathrm{C}^{\mathrm{cdc} 20}$ indirectly regulate the cohesion structure (indicated by broken line). Full line T shows the inhibitive effects of two factors; (B) Premature activation of separase, Sgo2 degradation, and the increase of oxidative damage and intracellular $\mathrm{pH}$ may be the leading cause of cohesion-ring structure cleavage during maternal aging.

\section{The Effects of Age-Related Loss of Cohesion}

\subsection{Destabilization of Chiasmata}

Chiasmata have long been recognized as a regular feature of meiosis and are the result of prior crossing over between homologous chromatids [88]. They are formed during fetal development and 
are not resolved until shortly before ovulation occurs in a sexually mature female. Segregation of homologous chromosomes during meiosis depends on chiasmata and sister chromatid cohesion at anaphase I [89] (Figure 3A). What is the relationship between chiasmata and cohesion? Bickel et al. demonstrated that Drosophila oocytes required sister-chromatid cohesion to maintain chiasmata between recombinant chromosomes [90]. In mammalian oocytes, it has been found that the cohesin Smc1 $\beta$ subunit acts as a chiasmata binder to stabilize sites of exchange until anaphase [9]. Rec 8 cleavage triggers chiasmata resolution during mouse meiosis I [34]. Thus, sister chromatid cohesion is required to stabilize chiasmata. In support of this conclusion, it was reported that this cohesion can also keep chiasma in place during meiosis I [88].
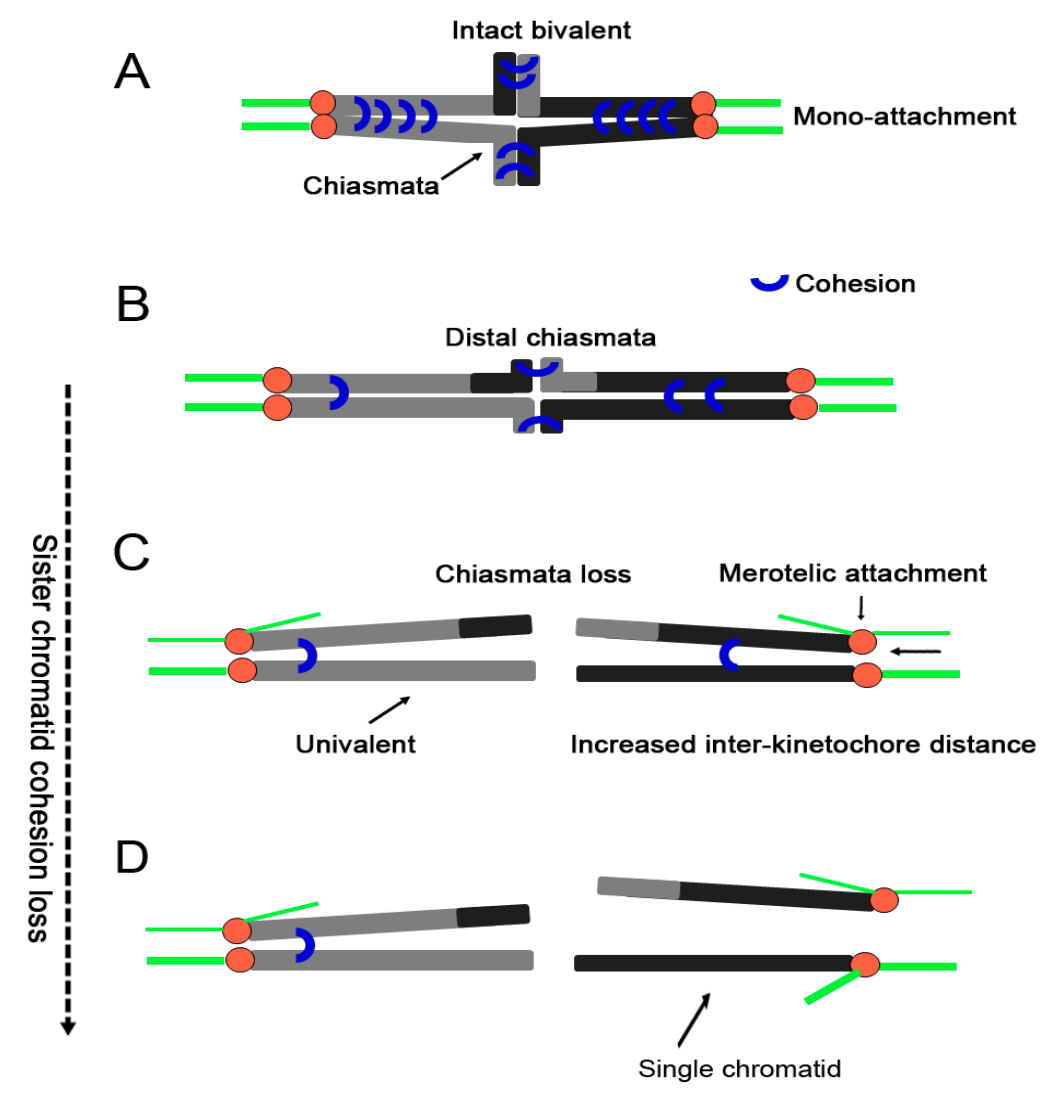

Figure 3. The effects of age-related cohesion loss. (A) An intact bivalent configuration is attached by an amphitelic microtubule bundle. The two sister chromatids of each homologous chromosome face towards the same spindle pole. The cohesion embraces the two sister chromatids at their centromeres and along the chromosome arm; (B) The chiasmata shift toward the distal chromosome with cohesion loss; (C) A bivalent configuration becomes two univalents at the time of chiasmata loss, which gives rise to arm cohesion deterioration; (D) Centromere cohesion loss can generate a single chromatid in oocytes. Centromere cohesion loss can cause an increase in sister inter-kinetochore distance, as well as the merotelic attachment of a sister kinetochore and the appearance of a single chromatid. Red circle, centromere; green line, microtubule.

Distally associated homologs without a visible chiasmata are prevalent in 14 month old mouse oocytes [7]. Meanwhile, reduced cohesion on chromosome arms is accompanied by an increase in distal chiasmata in old mouse oocytes ([32], detailed in the supplementary material), which is consistent with the idea that there is a shift toward distal chiasmata in oocytes from aged mice [91] (Figure 3B). In other words, a defect in cohesion distal to crossover sites results in a shift of chiasmata placement (chiasmata slippage; Figure 3B) or even premature bivalent separation in mouse meiosis I (Figure 3C). Thus, destabilization of chiasmata in association with cohesin depletion is a general feature of mouse 
aging. In addition, bivalents, whose integrity is compromised by destabilization of chiasmata [88,92], would be unable to establish the tension required for stable biorientation of homologs.

In humans, the placement of crossover (chiasmata) sites varies according to gender. In females, chromosomes tend to have more crossover sites than males, and longer chromosomes form more crossovers than shorter ones $[93,94]$. When crossover sites form close to telomeres, reduced amounts of cohesin may link homologous chromosomes, whereas crossover sites within centromeres may compromise sister chromatid cohesion or prevent the removal of cohesins, which causes nondisjunction errors $[95,96]$. Researchers have proposed that a minimal amount of the sister chromatid cohesion complex remaining distal to the exchange event is expected to increase the risk of meiosis I errors $[96,97]$.

\subsection{Bivalents Separation into Univalents}

The configuration of two linked homologous chromosomes is called bivalent (Figure 3A). The integrity of bivalents is crucial for accurate chromosome segregation. Weakly attached bivalents are common and some bivalents can even split into individual chromosomes, called univalent, because of cohesion loss in aged human and mouse oocytes [11,13,69]. Sakakibara et al. found that bivalent separation precedes the majority of segregation errors during meiosis I in aged mouse oocytes, and they also determined that univalents are predisposed to predivision in human oocytes through chromosome tracking [11]. The prevalence of univalents increases dramatically with age and occurs in $40 \%$ of oocytes from women older than 35 compared with $10 \%$ of oocytes from women who are 30-35 years of age [13]. Age-related cohesion loss within bivalents is not restricted to centromeric regions. Cohesion linking of homologous chromosomes is also compromised. For example, $S m c 1 \beta$-knockout oocytes that have a reduced amount of cohesin exhibit an age-related increase in univalents [9]. Tobacco etch virus-induced Rec8 cleavage triggers chiasmata resolution and converts bivalents to univalents [34]. Separated sister kinetochores allow bivalents to rotate and twist by 90 degrees on the spindle in aged human oocytes [13]. These studies all indicate that age-related cohesion loss can cause bivalent configurations to separate into univalent configurations (Figure 3C). The fate of these univalents may be to bi-orientate and so divide equationally in metaphase I (MI) [15]. Alternatively, they may divide intact during MI and form interactions with microtubules that satisfy the SAC without bi-orientation [15], which is similar to the results for some univalents from the $\mathrm{XO}$ mice that have been reported [98]. However, both situations may cause chromosome segregation errors and aneuploidy. Thus, how to reduce this phenomenon is an outstanding problem that we should attempt to solve in the future.

\subsection{Kinetochore Orientation Alteration}

Chromosomes must establish stable biorientation prior to anaphase to achieve faithful segregation during cell division [99]. In meiosis I, sister chromatids become attached from the same pole and co-segregate, and homologous chromosomes connected by chiasmata segregate to opposite poles. In meiosis II, sister chromatids become attached at the kinetochore by spindle microtubules emanating from opposite poles and are segregated equationally. There are stochastic interactions between microtubules and kinetochores through the "search and capture" mechanism [100,101]. Therefore, two-thirds of all biorientation attempts were erroneous and that $86 \%$ of all homologous chromosomes required error corrections of their kinetochore microtubule attachments before they established a stable biorientation in mouse oocytes [99].

When a single kinetochore binds microtubules that are oriented toward both spindle poles, a prominent error called merotely will occur [102-104]. Researchers indicate that the mitotic spindle checkpoint cannot detect this attachment orientation, which can induce chromosome lag during anaphase $[103,105]$. Consistent with mitotic anaphase, merotelic attachment persists during meiotic anaphase II and could cause chromosome lag and tailing [106,107]. Tension established through merotelic attachment of chromatids can maintain spindle checkpoint inactivation, which promotes chromatid transmission and the formation of aneuploid cells [103,107]. In mitotic and cancer 
cells, merotelically attached kinetochores are a major mechanism of aneuploidy and chromosomal instability $[103,108]$. In old mouse oocytes, this orientation has a significant increase and has been introduced as a lesion to explain aneuploidy in meiosis I and meiosis II [12,106]. Therefore, merotelic attachment may be one of the leading factors to cause age-related aneuploidy.

Cohesion-mediated association of homologous chromosomes promotes proper orientation and microtubule attachments in the meiosis I spindle [100]. Because cohesion makes sister kinetochores behave as a single kinetochore unit during meiosis I, sister kinetochores tend to attach to microtubules in a syntelic manner to make sure that the bivalent configuration is captured from opposite poles and sister kinetochores of each bivalent face towards the same spindle pole. When cohesion is lost, the tension balance of bivalent is broken. For evading surveillance mechanisms that monitor tension, new tension will come from merotelic kinetochore attachment. Furthermore, the cohesin subunit Rec8 has been reported to play an important role in the mono-orientation of sister kinetochores [24]. Sister chromatids are aligned at the metaphase equator by tension balance between poleward pulling forces and sister chromatid cohesion during meiosis II [100]. In other words, cohesion produces tension by counteracting the pulling force of microtubules that capture kinetochores from opposite poles. Therefore, this tension has a crucial role in stabilizing monopolar attachment of kinetochores. In cells, weakened centromeric cohesion has been reported to trigger merotelic attachment $[103,109]$. In addition, subtle defects in cohesion can disrupt centromere geometry by altering the normal back-to-back configuration of sister kinetochores to increase the formation rate of merotelic attachments [110]. In brief, we speculate that weakened cohesion plays an important role in the increase of merotelic kinetochore attachment in aged oocytes (Figure 3C).

In human oocytes, having separated sister kinetochores increases the risk of merotelic kinetochore-microtubule attachments [13] (Figure 3C). The distance between kinetochores reflects differences in cohesion holding the centromeres together. Increased interkinetochore distances have been found in old mouse and human oocytes [3,32,111]. In mouse oocytes, the distance is $0.25 \mu \mathrm{m}$ at 3 months old, but reaches $0.38 \mu \mathrm{m}$ by 12 months old. In 15 month old mice, the average distance even reaches $0.82 \mu \mathrm{m}$ [3]. In human oocytes, the average interkinetochore distance increases from $0.82 \pm 0.03 \mu \mathrm{m}$ in the youngest females (16.4 years) to $1.1 \pm 0.03 \mu \mathrm{m}$ in the oldest humans (37.3 years) [111]. When the distance between kinetochores is long enough, a single chromatid would appear, which indicates complete loss of centromere cohesion (Figure 3D). This event is called precocious separation of sister chromatids, which is the main defect found in older mice during MII arrest [69].

\section{Conclusions and Future Perspectives}

Experiments in mouse and human oocytes have shown that cohesion loss increases with maternal age, which is a major mechanism of age-related aneuploidy $[7,32,33,111]$. In this review, we explain how cohesion deterioration in aged oocytes occurs due to the premature loss of Sgo2 protein, the increased sensibility of separase, the SAC and $\mathrm{APC} / \mathrm{C}^{\mathrm{Cdc} 20}$, and oxidative damage (Figure 2). These factors alone or together may influence the strength of cohesion with advanced maternal age. However, how to avoid these factors as female age remains unknown. On the other hand, we also discuss the effects of cohesion deterioration on chiasmata stabilization, bivalent integrity, kinetochore orientation and sister kinetochore distance (Figure 3), which all have a direct connection to chromosome segregation. A greater understanding of the causes and effects of cohesion deterioration during maternal aging may provide opportunities to counteract age-related deterioration of chromosome structures. Caloric restriction (CR) does not reveal age-related increase in oocyte aneuploidy or chromosomal misalignment in rodents [112], and improves postnatal survival of offspring delivered by older females [113]. The percentages of aneuploidy and diploidy significantly decrease in females fed an antioxidant (the mixture of vitamin $C$ and vitamin $E$ ) diet comparing with those in control [83]. In addition, it has been reported that the antioxidant melatonin can prevent postovulatory oocyte aging in pigs [114] and mice [115]. The catalase can protect chromosomes from oxidative damages 
during meiotic maturation in mouse oocytes [116]. Given that age-related cohesion loss is a leading cause of the increase in aneuploidy with advanced maternal age, CR and antioxidants may have a positive effect on maintaining sister chromatid cohesion during maternal aging. Despite the beneficial effect of oral antioxidant administration and CR on oocyte quality, transference of antioxidants and CR to human beings should be made with caution because many undesirable systemic disorders may induce reproductive disturbances, such as pharmacological doses of vitamins $C$ and E. How to maintain oocyte quality and reduce age-related cohesion deterioration during maternal aging are still great challenges for researchers.

Acknowledgments: This work was supported by grants from Major Research Plan "973" Project (2012CB944702), LNCCC-D50-2015, LNCCC-C09-2015, Natural Science Foundation of China (31501953, 31471352, 31471400, 81270662 and 31171380) and Academician Workstation Support (Shenyang, Changsha and Shandong).

Author Contributions: Jin-Mei Cheng wrote the paper. Yi-Xun Liu conceived the paper.

Conflicts of Interest: The authors declare no conflict of interest.

\section{References}

1. Anifandis, G.; Markandona, O.; Dafopoulos, K.; Messini, C.; Tsezou, A.; Dimitraki, M.; Georgoulias, P.; Daponte, A.; Messinis, I. Embryological Results of Couples Undergoing ICSI-ET Treatments with Males Carrying the Single Nucleotide Polymorphism rs175080 of the MLH3 Gene. Int. J. Mol. Sci. 2017, 18, 314. [CrossRef] [PubMed]

2. Cheng, J.M.; Li, J.; Tang, J.X.; Cheng, S.R.; Deng, S.L.; Jin, C.; Zhang, Y.; Wang, X.X.; Zhou, C.X.; Liu, Y.X. Elevated intracellular $\mathrm{pH}$ appears in aged oocytes and causes oocyte aneuploidy associated with the loss of cohesion in mice. Cell Cycle 2016, 18, 2454-2463. [CrossRef] [PubMed]

3. Merriman, J.A.; Jennings, P.C.; McLaughlin, E.A.; Jones, K.T. Effect of aging on superovulation efficiency, aneuploidy rates, and sister chromatid cohesion in mice aged up to 15 months. Biol. Reprod. 2011, 49, 1-6.

4. Camlin, N.J.; McLaughlin, E.A.; Holt, J.E. The use of C57Bl/6 $\times$ CBA F1 hybrid cross as a model for human age-related oocyte aneuploidy. Mol. Reprod. Dev. 2017, 84, 6-7.

5. Fragouli, E.; Alfarawati, S.; Goodall, N.N.; Sanchez-Garcia, J.F.; Colls, P.; Wells, D. The cytogenetics of polar bodies: Insights into female meiosis and the diagnosis of aneuploidy. Mol. Hum. Reprod. 2011, 17, $286-295$. [CrossRef] [PubMed]

6. Kuliev, A.; Zlatopolsky, Z.; Kirillova, I.; Spivakova, J.; Cieslak, J. Meiosis errors in over 20,000 oocytes studied in the practice of preimplantation aneuploidy testing. Reprod. Biomed. Online 2011, 22, 2-8. [CrossRef] [PubMed]

7. Lister, L.M.; Kouznetsova, A.; Hyslop, L.A.; Kalleas, D.; Pace, S.L.; Barel, J.C.; Nathan, A.; Floros, V.; Adelfalk, C.; Watanabe, Y.; et al. Age-related meiotic segregation errors in mammalian oocytes are preceded by depletion of cohesin and Sgo2. Curr. Biol. 2010, 20, 1511-1521. [CrossRef] [PubMed]

8. Jessberger, R. Age-related aneuploidy through cohesion exhaustion. EMBO Rep. 2012, 13, 539-546. [CrossRef] [PubMed]

9. Hodges, C.A.; Revenkova, E.; Jessberger, R.; Hassold, T.J.; Hunt, P.A. SMC1 $\beta$-deficient female mice provide evidence that cohesins are a missing link in age-related nondisjunction. Nat. Genet. 2005, 37, 1351-1355. [CrossRef] [PubMed]

10. Chiang, T.; Schultz, R.M.; Lampson, M.A. Meiotic origins of maternal age-related aneuploidy. Biol. Reprod. 2012, 86, 1-7. [CrossRef] [PubMed]

11. Sakakibara, Y.; Hashimoto, S.; Nakaoka, Y.; Kouznetsova, A.; Hoog, C.; Kitajima, T.S. Bivalent separation into univalents precedes age-related meiosis I errors in oocytes. Nat. Commun. 2015, 6, 7550. [CrossRef] [PubMed]

12. Shomper, M.; Lappa, C.; FitzHarris, G. Kinetochore microtubule establishment is defective in oocytes from aged mice. Cell Cycle 2014, 13, 1171-1179. [CrossRef] [PubMed]

13. Zielinska1, A.P.; Holubcova, Z.; Blayney, M.; Elder, K.; Schuh, M. Sister kinetochore splitting and precocious disintegration of bivalents could explain the maternal age effect. Elife 2015, 4, e11389. [CrossRef] [PubMed] 
14. Patel, J.; Tan, S.L.; Hartshorne, G.M.; McAinsh, A.D. Unique geometry of sister kinetochores in human oocytes during meiosis I may explain maternal age-associated increases in chromosomal abnormalities. Biol. Open 2015, 5, 178-184. [CrossRef] [PubMed]

15. Jones, K.T.; Lane, S.I. Molecular causes of aneuploidy in mammalian eggs. Development 2013, 140, 3719-3730. [CrossRef] [PubMed]

16. Wood, A.J.; Severson, A.F.; Meyer, B.J. Condensin and cohesin complexity: The expanding repertoire of functions. Nat. Rev. Genet. 2010, 11, 391-404. [CrossRef] [PubMed]

17. Uhlmann, F. Chromosome cohesion and segregation in mitosis and meiosis. Curr. Opin. Cell. Biol. 2001, 13, 754-761. [CrossRef]

18. Nasmyth, K.; Haering, C.H. Cohesin: Its roles and mechanisms. Annu. Rev. Genet. 2009, 43, 525-558. [CrossRef] [PubMed]

19. Revenkova, E.; Eijpe, M.; Heyting, C.; Gross, B.; Jessberger, R. Novel meiosis-specific isoform of mammalian SMC1. Mol. Cell. Biol. 2001, 21, 6984-6998. [CrossRef] [PubMed]

20. Revenkova, E.; Eijpe, M.; Heyting, C.; Hodges, C.A.; Hunt, P.A.; Liebe, B.; Scherthan, H.; Jessberger, R. Cohesin SMC1 $\beta$ is required for meiotic chromosome dynamics, sister chromatid cohesion and DNA recombination. Nat. Cell. Biol. 2004, 6, 555-562. [CrossRef] [PubMed]

21. Hirano, T. At the heart of the chromosome: SMC proteins in action. Nat. Rev. Mol. Cell. Biol. 2006, 7, 311-322. [CrossRef] [PubMed]

22. Garcia-Cruz, R.; Brieno, M.A.; Roig, I.; Grossmann, M.; Velilla, E.; Pujol, A.; Cabero, L.; Pessarrodona, A.; Barbero, J.L.; Garcia Caldés, M. Dynamics of cohesin proteins REC8, STAG3, SMC1 $\beta$ and SMC3 are consistent with a role in sister chromatid cohesion during meiosis in human oocytes. Hum. Reprod. 2010, 25, 2316-2332. [CrossRef] [PubMed]

23. Schleiffer, A.; Kaitna, S.; Maurer-Stroh, S.; Glotzer, M.; Nasmyth, K.; Eisenhaber, F. Kleisins: A superfamily of bacterial and eukaryotic SMC protein partners. Mol. Cell. 2003, 11, 571-575. [CrossRef]

24. Watanabe, Y.; Nurse, P. Cohesin Rec8 is required for reductional chromosome segregation at meiosis. Nature 1999, 400, 461-464. [CrossRef] [PubMed]

25. Parisi, S.; McKay, M.J.; Molnar, M.; Thompson, M.A.; van der Spek, P.J.; Drunen Schoenmaker, E.; van Kanaar, R.; Lehmann, E.; Hoeijmakers, J.H.; Kohli, J. Rec8p, a meiotic recombination and sister chromatid cohesion phosphoprotein of the Rad21p family conserved from fission yeast to humans. Mol. Cell. Biol. 1999, 19, 3515-3528. [CrossRef] [PubMed]

26. Prieto, I.; Suja, J.A.; Pezzi, N.; Kremer, L.; Martínez-A, C.; Rufas, J.S.; Barbero, J.L. Mammalian STAG3 is a cohesin specific to sister chromatid arms in meiosis I. Nat. Cell. Biol. 2001, 3, 761-766. [CrossRef] [PubMed]

27. Pezzi, N.; Prieto, I.; Kremer, L.; Perez Jurado, L.A.; Valero, C.; Del Mazo, J.; Martinez, A.C.; Barbero, J.L. STAG3, a novel gene encoding a protein involved in meiotic chromosome pairing and location of STAG3-related genes flanking the Williams-Beuren syndrome deletion. FASEB J. 2000, 14, 581-592. [PubMed]

28. Xu, H.; Beasley, M.D.; Warren, W.D.; van der Horst, G.T.; McKay, M.J. Absence of mouse REC8cohesin promotes synapsis of sister chromatids in meiosis. Dev. Cell. 2005, 8, 949-961. [CrossRef] [PubMed]

29. Klein, F.; Mahr, P.; Galova, M.; Buonomo, S.B.; Michaelis, C.; Nairz, K.; Nasmyth, K. A central role for cohesins in sister chromatid cohesion, formation of axial elements, and recombination during yeast meiosis. Cell 1999, 1, 91-103. [CrossRef]

30. Eijpe, M.; Offenberg, H.; Jessberger, R.; Revenkova, E.; Heyting, C. Meiotic cohesin REC8 marks the axial elements of rat synaptonemal complexes before cohesins SMC1beta and SMC3. J. Cell. Biol. 2003, 160, 657-670. [CrossRef] [PubMed]

31. Kudo, N.R.; Anger, M.; Peters, A.H.F.M.; Stemmann, O.; Theussl, H.C.; Helmhart, W.; Kudo, H.; Heyting, C.; Nasmyth, K. Role of cleavage by separase of the Rec8 kleisin subunit of cohesin during mammalian meiosis I. J. Cell. Sci. 2009, 122, 2686-2698. [CrossRef] [PubMed]

32. Chiang, T.; Duncan, F.E.; Schindler, K.; Schultz, R.M.; Lampson, M.A. Evidence that weakened centromere cohesion is a leading cause of age-related aneuploidy in oocytes. Curr. Biol. 2010, 20, 1522-1528. [CrossRef] [PubMed]

33. Liu, L.; Keefe, D.L. Defective cohesin is associated with age-dependent misaligned chromosomes in oocytes. Reprod. Biomed. Online 2008, 1, 103-112. [CrossRef] 
34. Tachibana-Konwalski, K.; Godwin, J.; van der Weyden, L.; Champion, L.; Kudo, N.R.; Adams, D.J.; Nasmyth, K. Rec8-containing cohesin maintains bivalents without turnover during the growing phase of mouse oocytes. Genes Dev. 2010, 24, 2505-2516. [CrossRef] [PubMed]

35. Burkhardt, S.; Borsos, M.; Szydlowska, A.; Hirota, T.; Saitou, M.; Tachibana-Konwalski, K. Chromosome Cohesion Established by Rec8-Cohesin in Fetal Oocytes Is Maintained without Detectable Turnover in Oocytes Arrested for Months in Mice. Curr. Biol. 2016, 26, 678-685. [CrossRef] [PubMed]

36. Revenkova, E.; Herrmann, K.; Adelfalk, C.; Jessberger, R. Oocyte cohesion expression restricted to predictyate stages provides full fertility and prevents aneuploidy. Curr. Biol. 2010, 20, 1529-1533. [CrossRef] [PubMed]

37. Weng, K.A.; Jeffreys, C.A.; Bickel, S.E. Rejuvenation of meiotic cohesion in oocytes during prophase I is required for chiasma maintenance and accurate chromosome segregation. PLoS Genet. 2014, 10, e1004607. [CrossRef] [PubMed]

38. Hauf, S.; Waizenegger, I.C.; Peters, J.M. Cohesin Cleavage by Separase Required for Anaphase and Cytokinesis in Human Cells. Science 2001, 5533, 1320-1323. [CrossRef] [PubMed]

39. Waizenegger, I.C.; Hauf, S.; Meinke, A.; Peters, J.M. Two distinct pathways remove mammalian cohesin from chromosome arms in prophase and from centromeres in anaphase. Cell 2000, 103, 399-410. [CrossRef]

40. Kudo, N.R.; Wassmann, K.; Anger, M.; Schuh, M.; Wirth, K.G.; Xu, H.; Helmhart, W.; Kudo, H.; McKay, M.; Maro, B.; et al. Resolution of chiasmata in oocytes requires separase-mediated proteolysis. Cell 2006, 126, 135-146. [CrossRef] [PubMed]

41. Herbert, M.; Levasseur, M.; Homer, H.; Yallop, K.; Murdoch, A.; McDougall, A. Homologue disjunction in mouse oocytes requires proteolysis of securin and cyclin B1. Nat. Cell. Biol. 2003, 5, 1023-1025. [CrossRef] [PubMed]

42. Stemmann, O.; Zou, H.; Gerber, S.A.; Gygi, S.P.; Kirschner, M.W. Dual inhibition of sister chromatid separation at metaphase. Cell 2001, 107, 715-726. [CrossRef]

43. Gorr, I.H.; Boos, D.; Stemmann, O. Mutual inhibition of separase and Cdk1 by two-step complex formation. Mol. Cell. 2005, 19, 135-141. [CrossRef] [PubMed]

44. Nabti, I.; Reis, A.; Levasseur, M.; Stemmann, O.; Jones, K.T. Securin and not CDK1/cyclin B1 regulates sister chromatid disjunction during meiosis II in mouse eggs. Dev. Biol. 2008, 321, 379-386. [CrossRef] [PubMed]

45. Chiang, T.; Schultz, R.M.; Lampson, M.A. Age-dependent susceptibility of chromosome cohesion to premature separase activation in mouse oocytes. Biol. Reprod. 2011, 85, 1279-1283. [CrossRef] [PubMed]

46. Peters, J.M. The anaphase promoting complex/cyclosome: A machine designed to destroy. Nat. Rev. Mol. Cell. Biol. 2006, 7, 644-656. [CrossRef] [PubMed]

47. Peters, J.M. The anaphase-promoting complex: Proteolysis in mitosis and beyond. Mol. Cell 2002, 9, 931-943. [CrossRef]

48. Musacchio, A.; Salmon, E.D. The spindle-assembly checkpoint in space and time. Nat. Rev. Mol. Cell. Biol. 2007, 8, 379-393. [CrossRef] [PubMed]

49. McGuinness, B.E.; Anger, M.; Kouznetsova, A.; Gil-Bernabe', A.M.; Helmhart, W.; Kudo, N.R.; Wuensche, A.; Taylor, S.; Hoog, C.; Novak, B.; et al. Regulation of APC/C activity in oocytes by a Bub1-dependent spindle assembly checkpoint. Curr. Biol. 2009, 19, 369-380. [CrossRef] [PubMed]

50. Wassmann, K.; Benezra, R. Mitotic checkpoints: From yeast to cancer. Curr. Opin. Genet. Dev. 2001, 11, 83-90. [CrossRef]

51. Fang, G.; Yu, H.; Kirschner, M.W. The checkpoint protein MAD2 and the mitotic regulator CDC20 form a ternary complex with the anaphase-promoting complex to control anaphase initiation. Genes Dev. 1998, 12, 1871-1883. [CrossRef] [PubMed]

52. Homer, H.A.; McDougall, A.; Levasseur, M.; Yallop, K.; Murdoch, A.P.; Herbert, M. Mad2 prevents aneuploidy and premature proteolysis of cyclin B and securin during meiosis I in mouse oocytes. Genes Dev. 2005, 19, 202-207. [CrossRef] [PubMed]

53. Wassmann, K.; Niault, T.; Maro, B. Metaphase I arrest upon activation of the Mad2-dependent spindle checkpoint in mouse oocytes. Curr. Biol. 2003, 18, 1596-1608. [CrossRef]

54. Perera, D.; Tilston, V.; Hopwood, J.A.; Barchi, M.; Boot-Handford, R.P.; Taylor, S.S. Bub1 maintains centromeric cohesion by activation of the spindle checkpoint. Dev. Cell 2007, 13, 566-579. [CrossRef] [PubMed]

55. Bernard, P.; Maure, J.F.; Javerzat, J.P. Fission yeast Bub1 is essential in setting up the meiotic pattern of chromosome segregation. Nat. Cell. Biol. 2001, 3, 522-526. [CrossRef] [PubMed] 
56. Kitajima, T.S.; Kawashima, S.A.; Watanabe, Y. The conserved kinetochore protein shugoshinprotects centromeric cohesion during meiosis. Nature 2004, 427, 510-517. [CrossRef] [PubMed]

57. Steuerwald, N.M.; Bermúdez, M.G.; Wells, D.; Munne, S.; Cohen, J. Maternal age-related differential global expression profiles observed in human oocytes. Reprod. BioMed. Online. 2007, 14, 700-708. [CrossRef]

58. Pan, H.; Ma, P.P.; Zhu, W.T.; Schultz, R.M. Age-associated increase in aneuploidy and changes in gene expression in mouse eggs. Dev. Biol. 2008, 316, 397-407. [CrossRef] [PubMed]

59. Steuerwald, N.; Cohen, J.; Herrera, R.J.; Sandalinas, M.; Brenner, C.A. Association between spindle assembly checkpoint expression and maternal age in human oocytes. Mol. Hum. Reprod. 2001, 7, 49-55. [CrossRef] [PubMed]

60. Yun, Y.; Holt, J.E.; Lane, S.I.; McLaughlin, E.A.; Merriman, J.A.; Jones, K.T. Reduced ability to recover from spindle disruption and loss of kinetochore spindle assembly checkpoint proteins in oocytes from aged mice. Cell Cycle 2014, 13, 1938-1947. [CrossRef] [PubMed]

61. Lagirand-Cantaloube, J.; Ciabrini, C.; Charrasse, S.; Ferrieres, A.; Castro, A.; Anahory, T.; Lorca, T. Loss of Centromere Cohesion in Aneuploid Human Oocytes Correlates with Decreased Kinetochore Localization of the Sac Proteins Bub1 and Bubr1. Sci. Rep. 2017, 7, 44001. [CrossRef] [PubMed]

62. Miao, Y.; Zhou, C.; Cui, Z.; Dai, X.; Zhang, M.; Lu, Y.; Xiong, B. Smc1 $\beta$ is required for activation of SAC during mouse oocyte meiosis. Cell Cycle 2017, 16, 536-544. [CrossRef] [PubMed]

63. Nabti, I.; Grimes, R.; Sarna, H.; Marangos, P.; Carroll, J. Maternal age-dependent APC/C-mediated decrease in securin causes premature sister chromatid separation in meiosis II. Nat. Commun. 2017, 8, 15346. [CrossRef]

64. Lee, J.; Kitajima, T.S.; Tanno, Y.; Yoshida, K.; Morita, T.; Miyano, T.; Miyake, M.; Watanabe, Y. Unified mode of centromeric protection by shugoshin in mammalian oocytes and somatic cells. Nat. Cell. Biol. 2008, 10, 42-52. [CrossRef] [PubMed]

65. Watanabe, Y. Shugoshin: Guardian spirit at the centromere. Curr. Opin. Cell. Biol. 2005, 17, 590-595. [CrossRef]

66. Llano, E.; Gomez, R.; Gutierrez-Caballero, C.; Herran, Y.; Sanchez-Martin, M.; Vazquez-Quinones, L.; Hernandez, T.; de Alava, E.; Cuadrado, A.; Barbero, J.L.; et al. Shugoshin-2 is essential for the completion of meiosis but not for mitotic cell division in mice. Genes. Dev. 2008, 22, 2400-2413. [CrossRef] [PubMed]

67. Rivera, T.; Losada, A. Shugoshin and PP2A, shared duties at the centromere. BioEssays 2006, 8, 775-779. [CrossRef]

68. Kitajima, T.S.; Sakuno, T.; Ishiguro, K.; Iemura, S.; Natsume, T.; Kawashima, S.A.; Watanabe, Y. Shugoshin collaborates with protein phosphatase $2 \mathrm{~A}$ to protect cohesin. Nature 2006, 441, 46-52. [CrossRef]

69. Yun, Y.; Lane, S.I.; Jones, K.T. Premature dyad separation in meiosis II is the major segregation error with maternal age in mouse oocytes. Development 2014, 141, 199-208. [CrossRef] [PubMed]

70. Hamant, O.; Golubovskaya, I.; Meeley, R.; Fiume, E.; Timofejeva, L.; Schleiffer, A.; Nasmyth, K.; Cande, W.Z. A REC8-dependent plant Shugoshin is required for maintenance of centromeric cohesion during meiosis and has no mitotic functions. Curr. Biol. 2005, 15, 948-954. [CrossRef] [PubMed]

71. Gandhi, R.; Gillespie, P.J.; Hirano, T. Human Wapl is a cohesin-binding protein that promotes sister-chromatid resolution in mitotic prophase. Curr. Biol. 2006, 24, 2406-2417. [CrossRef]

72. Kueng, S.; Hegemann, B.; Peters, B.H.; Lipp, J.J.; Schleiffer, A.; Mechtler, K.; Peters, J.M. Wapl controls the dynamic association of cohesin with chromatin. Cell 2006, 127, 955-967. [CrossRef]

73. Rankin, S.; Ayad, N.G.; Kirschner, M.W. Sororin, a substrate of the anaphase-promoting complex, is required for sister chromatid cohesion in vertebrates. Mol. Cell 2005, 18, 185-200. [CrossRef]

74. Lafont, A.L.; Song, J.; Rankin, S. Sororin cooperates with the acetyltransferase Eco2 to ensure DNA replication-dependent sister chromatid cohesion. Proc. Natl. Acad. Sci. USA 2010, 107, 20364-20369. [CrossRef] [PubMed]

75. Nishiyama, T.; Ladurner, R.; Schmitz, J.; Kreidl, E.; Schleiffer, A.; Bhaskara, V.; Bando, M.; Shirahige, K.; Hyman, A.A.; Mechtler, K.; et al. Sororin mediates sister chromatid cohesion by antagonizing Wapl. Cell 2010, 143, 737-749. [CrossRef]

76. Hara, K.; Zheng, G.; Qu, Q.; Liu, H.; Ouyang, Z.; Chen, Z.; Tomchick, D.R.; Yu, H. Structure of cohesin subcomplex pinpoints direct shugoshin-Wapl antagonism in centromeric cohesion. Nat. Struct. Mol. Biol. 2014, 21, 864-870. [CrossRef] [PubMed]

77. Tarín, J.J. Potential effects of age-associated oxidative stress on mammalian oocytes/embryos. Mol. Hum. Reprod. 1996, 2, 717-724. [CrossRef] 
78. Tian, L.; Cai, Q.; Wei, H. Alterations of antioxidant enzymes and oxidative damage to macromolecules in different organs of rats during aging. Free. Radic. Biol. Med. 1998, 24, 1477-1484. [CrossRef]

79. Martin, I.; Grotewiel, M.S. Oxidative damage and age-related functional declines. Mech. Ageing Dev. 2006, 127, 411-423. [CrossRef]

80. Muller, F.L.; Lustgarten, M.S.; Jang, Y.; Richardson, A.; Van Remmen, H. Trends in oxidative aging theories. Free Radic. Biol. Med. 2007, 43, 477-503. [CrossRef] [PubMed]

81. Agarwal, A.; Aponte-Mellado, A.; Premkumar, B.J.; Shaman, A.; Gupta, S. The effects of oxidative stress on female reproduction: A review. Reprod. Biol. Endocrinol. 2012, 10, 49. [CrossRef]

82. Devine, P.J.; Perreault, S.D.; Luderer, U. Roles of reactive oxygen species and antioxidants in ovarian toxicity. Biol. Reprod. 2012, 27, 1-10.

83. Tarín, J.J.; Vendrell, F.J.; Ten, J.; Cano, A. Antioxidant therapy counteracts the disturbing effects of diamide and maternal ageing on meiotic division and chromosomal segregation in mouse oocytes. Mol. Hum. Reprod. 1998, 4, 281-288. [CrossRef]

84. Perkins, A.T.; Das, T.M.; Panzera, L.C.; Bickel, S.E. Oxidative stress in oocytes during midprophase induces premature loss of cohesion and chromosome segregation errors. Proc. Natl. Acad. Sci. 2016, 113, E6823-E6830. [CrossRef]

85. Yamauchi, Y.; Boukari, H.; Banerjee, I.; Sbalzarini, I.F.; Horvath, P.; Helenius, A. Histone deacetylase 8 is required for centrosome cohesion andinfluenza A virus entry. PLoS Pathog. 2011, 7, e1002316. [CrossRef] [PubMed]

86. Deardoff, M.A.; Bando, M.; Nakato, R.; Watrin, E.; Itoh, T.; Minamino, M.; Saitoh, K.; Komata, M.; Katou, Y.; Clark, D. HDAC8 mutations in Cornelia de Lange syndrome affect the cohesin acetylation cycle. Nature 2012, 489, 313-317. [CrossRef]

87. Nasmyth, K. Cohesin: A catenase with separate entry and exitgates? Nat. Cell. Biol. 2011, 13, 1170-1177. [CrossRef]

88. Carpenter, A.T.C. Chiasma function. Cell 1994, 7, 959-962. [CrossRef]

89. Martinez-Perez, E.; Schvarzstein, M.; Barroso, C.; Lightfoot, J.; Dernburg, A.F.; Villeneuve, A.M. Crossovers trigger a remodeling of meiotic chromosome axis composition that is linked to two-step loss of sister chromatid cohesion. Genes Dev. 2008, 22, 2886-2901. [CrossRef] [PubMed]

90. Bickel, S.E.; Orr-Weaver, T.L.; Balicky, E.M. The sister-chromatid cohesion protein ORD is required for chiasma maintenance in Drosophila oocytes. Curr. Biol. 2002, 12, 925-929. [CrossRef]

91. Henderson, S.A.; Edwards, R.G. Chiasma frequency and maternal age in mammals. Nature 1968, 218, $22-28$. [CrossRef]

92. Nilsson, N.O.; Sall, T. A model of chiasma reduction of closely formed crossovers. J. Theor. Biol. 1995, 7, 93-98. [CrossRef] [PubMed]

93. Broman, K.W.; Murray, J.C.; Sheffield, V.C.; White, R.L.; Weber, J.L. Comprehensive human genetic maps: Individual and sex-specific variation in recombination. Am. J. Hum. Genet. 1998, 63, 861-869. [CrossRef]

94. Gruhn, J.R.; Al-Asmar, N.; Fasnacht, R.; Maylor-Hagen, H.; Peinado, V.; Rubio, C.; Broman, K.W.; Hunt, P.A.; Hassold, T. Correlations between synaptic initiation and meiotic recombination: A study of humans and mice. Am. J. Hum. Genet. 2016, 98, 102-115. [CrossRef]

95. Lamb, N.E.; Feingold, E.; Savage, A.; Avramopoulos, D.; Freeman, S.; Gu, Y.C.; Hallberg, A.; Hersey, J.; Karadima, G.; Pettay, D.; et al. Characterization of susceptible chiasma configurations that increase the risk for maternal nondisjunction of chromosome 21. Hum. Mol. Genet. 1997, 6, 1391-1399. [CrossRef]

96. Oliver, T.R.; Tinker, S.W.; Allen, E.G.; Hollis, N.; Locke, A.E.; Bean, L.J.; Chowdhury, R.; Begum, F.; Marazita, M.; Cheung, V.; et al. Altered patterns of multiple recombinant events are associated with nondisjunction of chromosome 21. Hum. Genet. 2012, 13, 1039-1046. [CrossRef]

97. Orr-Weaver, T. Meiotic nondisjunction does the two-step. Nat Genet. 1996, 14, 374-376. [CrossRef]

98. LeMaire-Adkins, R.; Radke, K.; Hunt, P.A. Lack of checkpoint control at the metaphase/anaphase transition: A mechanism of meiotic nondisjunction in mammalian females. J. Cell. Biol. 1997, 139, 1611-1619. [CrossRef] [PubMed]

99. Kitajima, T.S.; Ohsugi, M.; Ellenberg, J. Complete kinetochore tracking reveals error-prone homologous chromosome biorientation in mammalian oocytes. Cell 2011, 146, 568-581. [CrossRef] [PubMed]

100. Watanabe, Y. Geometry and force behind kinetochore orientation: Lessons from meiosis. Nat Rev. Mol. Cell. Biol. 2012, 13, 370-382. [CrossRef] 
101. Wittmann, T.; Hyman, A.; Desai, A. The spindle: A dynamic assembly of microtubules and motors. Nat. Cell. Biol. 2001, 3, E28-E34. [CrossRef]

102. Salmon, E.D.; Cimini, D.; Cameron, L.A.; Deluca, J.G. Merotelic kinetochores in mammalian tissue cells. Philos. Trans. R. Soc. Lond. B. Biol. Sci. 2005, 360, 553-568. [CrossRef]

103. Cimini, D.; Howell, B.; Maddox, P.; Khodjakov, A.; Degrassi, F.; Salmon, E.D. Merotelic kinetochore orientation is a major mechanism of aneuploidy in mitotic mammalian tissue cells. J. Cell. Biol. 2001, 153, 517-527. [CrossRef]

104. Gregan, J.; Polakova, S.; Zhang, L.J.; Tolic'-Nørrelykke, I.M.; Cimini, D. Merotelic kinetochore attachment: Causes and effects. Trends Cell Biol. 2011, 21, 374-381.

105. Cimini, D.; Fioravanti, D.; Salmon, E.D.; Degrassi, F. Merotelic kinetochore orientation versus chromosome mono-orientation in the origin of lagging chromosomes in human primary cells. J. Cell. Sci. 2002, 115, 507-515.

106. Cheng, J.M.; Li, J.; Tang, J.X.; Hao, X.X.; Wang, Z.P.; Sun, T.C.; Wang, X.X.; Zhang, Y.; Chen, S.R.; Liu, Y.X. Merotelic kinetochore attachment in oocyte meiosis II causes sister chromatids segregation errors in aged mice. Cell Cycle 2017, accepted.

107. Kouznetsova, A.; Hernandez-Hernandez, A.; Hoog, C. Merotelic attachments allow alignment and stabilization of chromatids in meiosis II oocytes. Nat. Commun. 2014, 5, 4409. [CrossRef] [PubMed]

108. Bakhoum, S.F.; Genovese, G.; Compton, D.A. Deviant kinetochore microtubule dynamics underlie chromosomal instability. Curr. Biol. 2009, 19, 1937-1942. [CrossRef]

109. Barber, T.D.; McManus, K.; Yuen, K.W.; Reis, M.; Parmigiani, G.; Shen, D.; Barrett, I.; Nouhi, Y.; Spencer, F.; Markowitz, S.; et al. Chromatid cohesion defects may underlie chromosome instability in human colorectal cancers. Proc. Natl. Acad. Sci. 2008, 105, 3443-3448. [CrossRef]

110. Orr, B.; Godek, K.M.; Compton, D. Aneuploidy. Curr. Biol. 2015, 25, R538-R542. [CrossRef] [PubMed]

111. Duncan, F.E.; Hornick, J.E.; Lampson, M.A.; Schultz, R.M.; Shea, L.D.; Woodruff, T.K. Chromosome cohesion decreases in human eggs with advanced maternal age. Aging Cell 2012, 11, 1121-1124. [CrossRef] [PubMed]

112. Selesniemi, K.; Lee, H.J.; Tilly, J.L. Moderate caloric restriction initiated in rodents during adulthood sustains function of the female reproductive axis into advanced chronological age. Aging Cell 2008, 7, 622-629. [CrossRef] [PubMed]

113. Selesniemi, K.; Lee, H.J.; Muhlhauser, A.; Tilly, J.L. Prevention of maternal aging-associated oocyte aneuploidy and meiotic spindle defects in mice by dietary and genetic strategies. Proc. Natl. Acad. Sci. 2011, 108, 12319-12324. [CrossRef]

114. Wang, T.; Gao, Y.Y.; Chen, L.; Nie, Z.W.; Cheng, W.; Liu, X.; Schatten, H.; Zhang, X.; Miao, Y.L. Melatonin prevents postovulatory oocyte aging and promotes subsequent embryonic development in the pig. Aging 2017, 9, 1552-1564. [CrossRef] [PubMed]

115. Lord, T.; Nixon, B.; Jones, K.T.; Aitken, R.J. Melatonin prevents postovulatory oocyte aging in the mouse and extends the window for optimal fertilization in vitro. Biol. Reprod. 2013, 88, 67. [CrossRef]

116. Park, Y.S.; You, S.Y.; Cho, S.; Jeon, H.J.; Lee, S.; Cho, D.H.; Kim, J.S.; Oh, J.S. Eccentric localization of catalase to protect chromosomes from oxidative damages during meiotic maturation in mouse oocytes. Histochem. Cell Boil. 2016, 146, 281-288. [CrossRef] [PubMed]

(C) 2017 by the authors. Licensee MDPI, Basel, Switzerland. This article is an open access article distributed under the terms and conditions of the Creative Commons Attribution (CC BY) license (http://creativecommons.org/licenses/by/4.0/). 